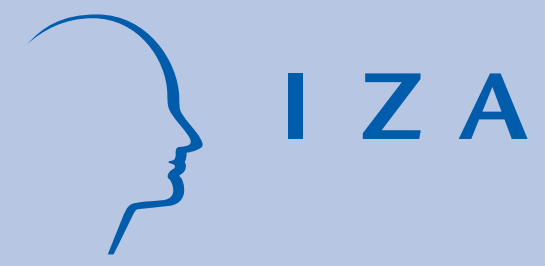

IZA Policy Paper No. 115

Inequality, Public Wealth, and the Federal Shareholder

Giacomo Corneo

October 2016 


\title{
Inequality, Public Wealth, and the Federal Shareholder
}

\author{
Giacomo Corneo \\ Free University of Berlin \\ and IZA
}

\section{Policy Paper No. 115 \\ October 2016}

\author{
IZA \\ P.O. Box 7240 \\ 53072 Bonn \\ Germany \\ Phone: +49-228-3894-0 \\ Fax: +49-228-3894-180 \\ E-mail: iza@iza.org
}

The IZA Policy Paper Series publishes work by IZA staff and network members with immediate relevance for policymakers. Any opinions and views on policy expressed are those of the author(s). IZA takes no institutional policy positions. The IZA research network is committed to the IZA Guiding Principles of Research Integrity.

The Institute for the Study of Labor (IZA) in Bonn is a local and virtual international research center and a place of communication between science, politics and business. IZA is an independent nonprofit organization supported by Deutsche Post Foundation.

The papers often represent preliminary work and are circulated to encourage discussion. Citation of such a paper should account for its provisional character. A revised version may be available directly from the corresponding author. 
IZA Policy Paper No. 115

October 2016

\section{ABSTRACT}

\section{Inequality, Public Wealth, and the Federal Shareholder ${ }^{*}$}

Current trends in the distribution of wealth trigger a social divide and threaten democracy in many advanced economies. I propose to counter this evolution by enhancing the role of public capital as a redistribution and empowerment device. The governance of public capital requires two novel institutions: a socially responsible Sovereign Wealth Fund and a Federal Shareholder. This paper offers an account of their possible design and sources of financing.

JEL Classification: HO, H5

Keywords: public ownership, redistribution

Corresponding author:

Giacomo Corneo

Department of Economics

Free University of Berlin

Boltzmannstr. 20

14195 Berlin

Germany

E-mail: giacomo.corneo@fu-berlin.de

* I thank Leonardo Becchetti, Angela Cummine, Massimo Florio, Volker Grossmann, Thorsten Hens, Olivier Jeanne, Katharina Jenderny, John Roemer and Paolo Vanin for helpful comments and Maximilian Stockhausen for research assistance. 


\section{Introduction}

Recent research on economic inequality has put forward the role played by the wealth distribution. Its centrality is suggested by a number of empirical findings, in particular the increase of top-wealth fractiles and aggregate wealth-income ratios over the last decades in several countries. In the United States for instance, the top 0.1 percent share of wealth has grown from 8 percent in the mid-1970s to 22 percent in 2012, according to Saez and Zucman (2016); during the same period, the aggregate wealth-income ratio has grown by about one fourth, according to Piketty and Zucman (2015). Such findings have aroused various concerns, chief among them the following ones:

(1) The effect of wealth inequality on income inequality is magnified by an unequal access to financial returns: large portfolios have access to substantially higher returns than smaller ones. Similarly to the labor market, an insider/outsider divide exists in financial markets which makes the dollar of an ordinary saver earn less than the dollar of a billionaire. ${ }^{1}$

(2) A large and increasing fraction of household net wealth is inherited rather than selfmade. In turn, inheritances are very unequally distributed. ${ }^{2}$

(3) The rise of wealth concentration increases the incentive and the ability of the wealthy to buy political influence, which in turn is used to further increase the concentration of economic power. ${ }^{3}$

Point (1) suggests that the bulk of the population faces a restricted access to financial markets and foregoes efficiency gains from pooling wealth together so as to reduce the sunk costs of financial investment and share its risk. Point (2) suggests that the birth lottery is gaining importance relative to individual merit as a determinant of the distribution of economic welfare in society. Point (3) suggests that incomes at the top of the distribution often result from rent-seeking activities rather than creating value for society. Taken together, those points cast serious doubts on the benign view of capitalism that has long been popularized by classical liberalism.

Both the details about (1)-(3) and their interpretation are controversial - which is unsurprising given limited data and the uncertainty about the right models to use to interpret them. There is, however, a relatively wide consensus that they deserve appropriate policy responses and such responses should not wait until all scientific controversies are resolved. The subsequent policy debate has mainly focused on Piketty's (2014) proposal to dramatically increase capital taxes. As cautioned e.g. by Stiglitz (2015), capital taxes pose a number of subtle issues in terms of incentives and shifting via general-equilibrium effects. It seems fair to say that we currently cannot predict with sufficient confidence the consequences of a large increase of capital taxes. Careful empirical simulations of the Laffer curve of capital taxation by Trabandt

\footnotetext{
${ }^{1}$ See e.g. Piketty (2014, ch. 12) and Atkinson (2015, ch. 6).

${ }^{2}$ See Piketty and Zucman (2015).

${ }^{3}$ See e.g. Lessig (2011), Stiglitz (2012, ch. 5) and Nichols and McChesney (2014).
} 
and Uhlig (2011) suggest that unintended consequences of raising capital taxes are likely, unless the tax increase is moderate.

In this paper I propose to tackle the problems associated with growing wealth inequality by means of a different strategy. In a nutshell, my proposal is to enhance the role of public ownership of capital through an evolutionary process of institution building. Public capital can namely be used to reduce the inequality in the distribution of primary capital incomes, making high capital taxes superfluous. As argued below, provided a sound governance structure is put in place, public ownership of capital of a certain kind has the potential to solve the problems raised by (1)-(3) above. It can break the vicious circle of increasing wealth concentration and political capture, contribute to more equality of opportunity, and reduce the transaction costs of financial investment.

My proposal borrows ideas from the literature on market socialism and blends them with insights from republicanism and the civil-economy tradition. ${ }^{4}$ Public capital in this proposal does not refer to infrastructure and utilities. It refers to forms of collective property that ground on democratic participation and are designed to limit inequality among the members of the community. ${ }^{5}$ The management of such a public capital requires suitable institutions that differ from existing ones and those that have been used for related purposes in the past. Admittedly, the institutions I depict in this proposal require an environment characterized by a sufficiently high quality of government and a sufficiently high level of social capital. Whilst certainly not existing everywhere, I surmise that several countries are currently endowed with such an environment that my proposal is relevant for them.

I propose that the public capital to be used as a tool for redistribution mainly take the form of stocks of publicly-quoted companies. Those stocks should be acquired by the government through market transactions and build a diversified international portfolio. Initially, such a public capital should entirely be managed by a sovereign wealth fund. Section 2 describes the prominent features of its governance structure, which include rules to prevent unethical investment. The sovereign wealth fund would contribute to reduce inequality by distributing its returns to citizens equally through a social dividend. While a sovereign wealth fund would merely act as a collective rentier, concerns for democracy call for some activation of public ownership inside the firms. Section 3 describes a novel public institution that could act as a controlling shareholder, referred to as the Federal Shareholder. That institution would replace private corporate control in some large firms, enable civil society to monitor those firms, and promote worker participation in their management. Its scope in the overall economy is not determined in advance; rather, it should be the outcome of a collective learning process about the costs and benefits of such a public-democratic control of companies as compared to private-capitalistic control. Of course, before public capital can be used as a tool to reduce

\footnotetext{
${ }^{4}$ See in particular Stauber (1987) and Roemer (1994) on market socialism, Dagger (2006) on republicanism and Bruni and Zamagni (2007) on the civil-economy paradigm.

${ }^{5}$ This perspective on redistribution has received scant attention by public economics, which rather focuses on how taxes and transfers should be set to solve the equity-efficiency tradeoff. The role of public ownership is investigated by the literature on incomplete contracting, but its focus is on issues of micro-governance rather than society-wide inequality.
} 
inequality and foster participation, it must be accumulated. Section 4 describes how a relatively large public capital can be built at small costs - using revenues from privatizations, government bonds, and moderate capital taxes.

\section{Socially responsible sovereign wealth fund}

Suppose that the polity owns through its government a large and diversified portfolio of stocks of publicly-quoted companies. Initially, the responsibility for managing such a public capital should rest entirely with a novel sovereign wealth fund (SWF) explicitly created for that purpose. ${ }^{6}$ SWFs have been around for more than sixty years now and at present there are more than fifty SWFs worldwide, including those in Australia, New Zealand, Norway and Alaska. SWFs are state-owned financial vehicles that manage public funds. Generally speaking, they operate like passive investors which seek to secure high rates of return by making appropriate portfolio decisions, without assuming control of business enterprises.

The main goal of the SWF I propose to establish is to allow every citizen to share in the high rates of return generated by the stock market. This should occur in a direct and transparent way, by earmarking the income of the SWF to finance a social dividend. This social dividend would be a monthly or quarterly universal transfer payment received by every citizen, and that everyone is free to use as she sees fit. ${ }^{7}$ It is the novel redistributive tool to be employed by the polity. It would be tax-exempted and would not be credited against benefits to which people are entitled by social legislation. The income of the fund would consist of its returns, net of administration costs and a reinvestment quota to stabilize the ratio of fund size to GDP in the long run. Because of the opportunities for diversification and the fact that it would not pay taxes, the SWF would over the long term yield an above-average return on capital for the citizens. This means that even those who have no private means of their own would benefit from the high returns generated by the stock market, since every citizen would be an equal shareholder, through the state, in the investments of the SWF. ${ }^{8}$

The social dividend would significantly contribute to reduce inequality, both of outcomes and opportunities. However, it is not realistic to expect that it would be as large as a basic income. Assume for example that over a time lapse of twenty years the polity gradually builds up a SWF that eventually amounts to $50 \%$ of GDP and that such a level is maintained forever. ${ }^{9}$ If the rate of return delivered to the public budget is $7 \%$, total expenditures for the social

\footnotetext{
${ }^{6}$ Corneo (2014a) discusses the potential role of a SWF from a European perspective. Atkinson (2015) proposes a SWF for the UK. A related proposal was put forward by Nobel laureate James Meade (1965). An overview on existing SWFs is offered by Quadrio Curzio and Miceli (2010).

${ }^{7}$ The entitlement may be contingent on a minimum number of years of main residence in the country. Persons under the age of eighteen could be entitled to half of the regular social dividend.

${ }^{8}$ Private households in their majority do not invest in stocks despite their high mean return - which constitutes a "participation puzzle" from the viewpoint of traditional models in financial economics. The literature has put forward various explanations for this puzzle: beyond fixed participation costs, lack of familiarity, loss aversion, narrow framing and limited cognitive ability contribute to explain why many households are unwilling to participate in the stock market (Barberis and Huang, 2008; Guiso et al., 2008; Grinblatt et al., 2011).

${ }^{9}$ By comparison, the market value of Norway's SWF is about twice that country's GDP.
} 
dividend will equal three and a half percentage points of GDP. For the U.S. this would imply today a social dividend of about 2,000 dollars per person per year. ${ }^{10}$ This is far from being sufficient to make a living but, especially for earners at the bottom of the distribution and large families, it would substantially contribute to improve their living conditions. The poverty rate would mechanically decrease by about one third. Using household data from the PSID and the tax simulation model of the NBER, TAXSIM, the share of the U.S. population falling below the official definition of poverty lines provided by the U.S. Census Bureau was $9.3 \%$ in 2012. A social dividend equal to three and a half percentage points of per-capita GDP would have reduced the poverty rate to $6.1 \%$.

In addition to its direct effect on the income distribution, the social dividend would reduce inequality by strengthening the bargaining power of low-skilled workers vis-à-vis their employers. Since the social dividend especially improves the fall-back option of the working poor, they can be expected to strike better pay bargains. This would empower vulnerable groups with few outside options that today are often left behind, both economically and politically.

Setting up this SWF would require an institutional framework that ensures both efficiency and democratic accountability. ${ }^{11}$ I propose that the SWF display the following three distinctive features. First, it should be so transparent that the citizens can easily monitor its investment strategy and its performance relative to that of other funds. Second, the SWF should be a faithful expression of the aspirations of the citizenry. Those aspirations are not limited to increasing the purchasing power of individuals. They also mirror deep concerns about the quality of human relationships in society and of man's relationships to nature. This broader view of the common good should be acknowledged by subjecting the fund's investment decisions to ethical requirements determined by a democratic process. This means that the SWF be prohibited from investing in companies that violate those ethical standards. ${ }^{12}$ This would generate a recurring public debate on endorsed values and broader social goals that would counteract political apathy and strengthen feelings of communality. As far as its portfolio management is concerned, the SWF would be similar to a socially responsible investment fund, such as those that have substantially grown worldwide over the last two decades. While this may come at a cost in terms of returns, this cost is likely to be negligible if the universe of investable stocks is large enough. ${ }^{13}$ Because of the large size of its portfolio, this ethical SWF would be a prominent financial investor. Thus, defining its ethical criteria

\footnotetext{
${ }^{10}$ This is a similar order of magnitude as the social dividend that is currently paid out by the Alaska Permanent Fund. That SWF was set up in 1976 by a liberal Republican governor, who introduced it after a referendum. Meanwhile, Alaska has gone from being the state with the most unequal income distribution to being one of the states with the lowest poverty and inequality in the US (Goldsmith, 2012; Standing, 2014).

${ }^{11}$ Al-Hassan et al. (2013) discuss various alternative governance structures for SWFs.

12 This is already the case in Norway. There, a Council of Ethics assesses whether specific companies should be excluded from the universe of potential stocks available for investment. Contributing to violations of human rights, promoting war, causing environmental damage and fostering corruption are among the reasons that may lead a company to be excluded.

13 This is suggested by empirical findings in Nofsinger and Varma (2012) and Becchetti et al. (2014) who also discuss informational reasons why, adjusting for risk, socially responsible funds perform similarly to conventional, unconstrained, funds.
} 
would not merely be the expression of a collective identity. It would also be a powerful tool in order to have companies paying more attention on how they decisions affect things like peace keeping, environmental sustainability, and the respect of human rights. Third, the SWF should be shielded from interference by both the government and the corporate sector. The need for avoiding capture is obvious and I will return shortly to the issue of granting independence from the government when discussing the second institution I propose, since in that case it arises in an even more acute fashion. ${ }^{14}$ The danger of capture by the corporate sector involves large firms and the financial industry, as both may profit from manipulating the investment decisions of the SWF. This suggests that the personnel of the SWF include civil servants and that strict rules minimize the risk of capture through revolving doors. Depending on countryspecific conditions, it might be recommendable to put a relatively low cap to the investment of the SWF in domestic firms or, at least, in domestic firms that are large relative to the domestic economy. This raises issues of definition and measurement - e.g. of ownership chains - that are not new to existing SWFs and can be tackled. ${ }^{15}$

The social dividend received by citizens would originate in the uncertain returns earned by the stock portfolio managed by the SWF. While stock returns are volatile, introducing a social dividend need not increase the income risk carried by citizens. For one thing, the SWF would distribute its income to the government, and the government's budget could be used to smooth the pay-outs to the citizens. E.g. in times of supernormal returns these could be used by the government to buy back the country's public debt and build a reserve that would be used to ensure that a stable social dividend is paid in times of subnormal returns. ${ }^{16}$ For another, the parliament may instruct the SWF to maximize its risk-adjusted return assessed from the viewpoint of a representative private household. To the extent that the SWF is able to invest in stocks whose returns are negatively correlated with the country's national income, the social dividend would actually reduce the volatility of private households' total incomes.

I recommend granting citizens the option to reinvest their social dividend in the SWF in a personal account instead of having it paid out on a regular basis. In this way, you could finance sabbatical years during the middle part of the life cycle and an annuity in old age.

Upon reaching adulthood, every citizen could, at any time, decide to open a sabbatical account, entailing the commitment to let her social dividend accumulate in such an account for a fixed number of years, say seven. During that period, her regular social dividends are reinvested in the SWF instead of being paid out. ${ }^{17}$ At the end, the holder of the account would receive the capitalized social dividends, a sum that would roughly suffice to finance a sabbatical year. This could be spent volunteering in the social economy, engaging in politics, and pursuing lifelong learning. Those activities may thus become ordinary events in most

\footnotetext{
${ }^{14}$ Bernstein et al. (2013) show that SWFs exposed to political influences are likely to exhibit major deviations from long-run return maximization.

${ }^{15}$ See e.g. Dietzenbacher and Temurshoev (2008) and Dorofeenko et al. (2008).

${ }^{16}$ As a by-product, this would help to stabilize the stock market.

17 The rate of return would be the one used by the government to set the social dividend. Hence it would depend on expected future returns rather than on the actual returns earned by the SWF. This would substantially reduce the risk burden carried by persons who choose to have their social dividend accumulate in their account.
} 
people's lives and generate far-reaching positive externalities. Employees would be entitled to unpaid leaves for sabbaticals in order to conduct such activities.

Starting at a later age, say forty, every citizen may choose to reinvest her social dividend in an old-age-provision account instead of a sabbatical account. The SWF may offer accounts with different lock-in periods, e.g. twenty, twenty-five and thirty years. Countries fighting against old-age poverty might even decide to make such old-age-provision accounts compulsory. At the end of the stipulated period, the accumulated amount would be transformed into an annuity, which the citizen would receive along with her social dividend; both would be taxexempted and not to be credited against social benefits. In countries that are severely hit by demographic aging, this form of saving would complement existing pay-as-you-go pension systems and avoid the high asset-management fees typically demanded by private insurance companies. Furthermore, as it is not linked to employment and the payment of social security contributions, this method of providing retirement income would not suffer from limited coverage but be available to everyone. ${ }^{18}$

Establishing such an ethical SWF and distributing a social dividend would thus not only contribute to reduce inequality but also rejuvenate public spiritedness, foster social freedom, and support universal old-age provision. At the same time, it would inaugurate a collective learning process about the management of public wealth. The institution of the SWF suits this learning process because its task is relatively well-understood and international experiences already exist upon which the polity can draw so as to successfully set up that institution and efficiently manage public wealth. As mentioned above, under such a SWF public capital plays a passive role in the participated firms. Once the polity has learnt to properly manage the SWF, public capital should start playing an active role. A novel institution should be created that challenges the capitalists on their own terrain, by contending with them for the control of large firms.

\section{Federal Shareholder}

A SWF can effectively counteract the developments (1) and (2) mentioned at the outset of this paper. But it would not imply major changes with respect to (3), i.e. it would not be a safeguard against the gradual subversion of democracy by a wealthy oligarchy. Large corporations and banks, and the lobbies that represent them, are also the main devices employed by the members of the moneyed elite to coordinate their endeavours and foster their interests in the public debate and the political arena. If the polity were only to own a few shares but not exercise any control in those corporations, the moneyed elite would still be able

\footnotetext{
${ }^{18}$ Empirical findings on lifetime earnings inequality in Germany (Bönke et al., 2015) and long-term earnings inequality in the U.S. (Kopczuk et al., 2010) suggest that younger cohorts find it increasingly difficult to save for retirement out of their wage income, especially the low skilled.
} 
to translate its wealth into political power in a way that fundamentally contradicts the democratic ideals of equality and participation. ${ }^{19}$

Therefore, the second stage of the strategy I propose entails the activation of public ownership in selected domestic companies. The beginning of that stage would be determined by a law that sets up a novel public institution explicitly designed to control companies. I have coined the term Federal Shareholder (FS) to refer to such an institution (Corneo, 2014b).

The initial financial endowment of the FS would stem from the SWF, from which it would likely also inherit some of its staff. The FS would use its endowment in order to acquire a majority stake in selected companies. Its first task is thus to identify the companies that are amenable to public control. These would mainly be publicly-quoted companies that have been under scrutiny by the SWF for some time, found to be relatively badly managed, and become the target of a hostile takeover by the FS. Badly managed corporations often survive thanks to lobbying and political protection and usually have plenty of technically competent employees that are dissatisfied with the current management and thus lack proper motivation. Hence, these are the corporations where there is the highest potential to raise economic value, curb rent-seeking activities, and combat plutocracy. The process of activating public ownership in the economy should not only be based on efficiency considerations, but also occur gradually. Therefore, the parliament should cap the initial capital endowment that is made available to the FS for getting in control of the firms. In its first years, only a tiny fraction of the sector of large firms would be under the control of the FS.

The FS may also acquire firms that are not publicly quoted and may also create new firms for instance in oligopoly-dominated industries. For reasons to be explained shortly, all firms of the FS should however go public within a certain delay. After some time, the ownership of the FS in those firms should equal $51 \%$ of their capital and that level should be maintained so long as the firm is under public control. The corresponding shares would be frozen in state ownership while the remaining ones would be freely traded in the stock market. The firms of the FS would thus display a mixed ownership structure and the FS would be their majority shareholder. Under the terms of the law on stock corporations, the FS would exercise leadership in the boards of directors or supervisory boards through its own personnel. Thus, the FS would require well-trained specialist personnel. In particular, it should be a centre of excellence for issues of corporate governance, investment analysis, financing and risk management. It should offer its staff interesting long-term career prospects and foster a sense of belonging and mission.

The mission of the FS should be clearly stated: profit maximization. Its firms are not utilities operating under natural monopoly but players that have to compete in global markets. Hence, profit maximization can be recommendable on efficiency grounds. The dividends from the shares owned by the FS would accrue to the government's budget and be earmarked to finance the social dividend - along with the income generated by the SWF.

\footnotetext{
${ }^{19}$ Morck et al. (2005) discuss why political influence depends on what one controls, rather than what one owns, and survey the literature on the economic distortions it creates.
} 
It might seem strange that the FS should retain the same profit goal the capitalists have although its profits benefit the whole citizenry via the social dividend - and not pursue any other social goal. But, as shown by the experience of public firms in several countries, charging them with social goals usually means confronting their managers with vaguely defined and ever changing objectives. This tends to eliminate accountability, making it almost impossible to evaluate their performance, and, at last, to deprive the managers of their sense of responsibility. In competitive markets, insisting that public firms be controlled by politicians is a proved recipe for financial and economic disaster. It is much better to incorporate social and environmental desiderata in the general legal framework - regulations and the tax system - which applies to all firms, independently of their ownership. Furthermore, it is advisable to cultivate a pluralistic economic environment that supports widespread entrepreneurship, small firms, and not-for-profit entities and that is conducive to satisfy people's demand for socially responsible forms of work, consumption, and investment. Crucially, while the objective of the firms under control of the FS should be the same as the alleged objective of capitalist firms, firms' behaviour will be systematically different in the two sectors. I will take up this point shortly.

As mentioned above, the firms of the FS would be quoted in the stock market and the FS should retain only $51 \%$ of their shares. Private ownership of the remaining $49 \%$ has a key role to play in creating an incentive structure that leads those public firms to maximize profits. Since private investors are free to buy and sell shares in the companies of the FS, the share price would reflect the market view of how well the management of these enterprises is performing. Hence, the information contained in the movement of share prices can be used to encourage managers of the public firms to pursue profit maximization. The novel stake of the polity in this matter implies that much more attention than today will be devoted to a careful regulation of the stock market and the design of appropriate incentive schemes for managers. That is, the reliance of the polity on the stock market for managing its capital will foster regulatory attempts aiming at fully exploiting the potential of the stock market as a discovery and information-generating device.

The second reason for having private minority ownership in the firms of the FS relates to the need of any pluralistic society for an array of checks and balances. Private shareholders can namely form associations and those associations would constitute influential interest groups which would put pressure on the management of the corporations of the FS to operate as profitably as possible.

In order to be able to fulfil its mission of maximizing long-run profits, the FS should be insulated from political pressure exerted by the government of the day. For instance, if a public firm is making losses and mass layoffs are necessary to restore its ability to compete, the FS should be free to restructure the firm even if the government opposes it. ${ }^{20}$ Granting the FS this type of autonomy requires a set of constitutional norms concerning the appointment and removal of its trustees and staff as well as their duties and prerogatives. I suggest that the

\footnotetext{
${ }^{20}$ I assume that decent unemployment benefits and effective labor market policies are in place.
} 
FS be endowed with a degree of political independence similar to the one enjoyed by some central banks - e.g. the Bundesbank in Germany. This would ensure that the public firms under the control of the FS cannot be abused by the government in order to accommodate special interests in view of the next election. The combination of a clear mission and political independence is a necessary precondition for a successful management of the public capital invested through the FS.

Since the FS contributes to finance the social dividend, every citizen is a stakeholder of that institution. Hence, there would be a public interest to scrutinize the performance of the FS, which calls for a duty of transparency on the part of the FS. Supporting its monitoring by the media and general public there should be an institutional supervision by an already existing authority, e.g. the central bank or the ministry of finance. In particular, that monitoring agency would publish the financial results of the companies under control of the FS along with the results achieved by relevant benchmark groups of companies. Furthermore, a portion of the remuneration paid to the staff of the FS would be performance-related, i.e. dependent on the relative performance of the controlled companies.

All arrangements described so far aim at enforcing profit maximization by the novel public institution in charge of controlling the firms. But for profit maximization to be good for society as a whole, it should not be pursued at the expense of the employees or the consumers or to the detriment of the natural environment; it should be the result of increased production efficiency and successful innovations. Regulations designed to protect employees, consumers and the natural environment so as to internalize externalities and enforce fair market competition should be enforced with respect to both public and private firms. But those under the control of the FS should be subject to additional checks by trade unions, consumer protection agencies and environmental associations - all acting as watchdogs on behalf of civil society. This would help to avoid instances of biased political protection in favour of the public firms. By way of an example, more intense monitoring by consumer protection agencies would counteract the government's temptation to increase public firms' profits by adopting a lax attitude toward anti-competitive behaviour.

The additional information rights of civil society would be defined by a law that grants its organizations facilitated access to monitor the firms of the FS so as to assess their compliance with regulatory norms. For that monitoring purpose, trade unions could enter a labour syndicate, consumer protection agencies a consumer syndicate, and environmental associations a natural-environment syndicate. Each syndicate would autonomously elect representatives to be sent as watchdogs to the various firms of the FS. The task of those representatives would be to inform their syndicate about firm behaviour that may violate existing regulatory norms - so that the syndicate's members can start initiatives in order to oppose that behaviour. Those watchdogs would also have the right to transmit to their syndicate information on firm behaviour that is not objectionable from a legal point of view but may be objectionable from the point of view of civil society. For instance, they might reveal that a firm of the FS operates utterly unsafe production plants in a foreign country that 
lacks proper security standards. However, they would be prohibited to reveal any business secret learnt through their monitoring activity that could be used by a firm's competitors. In such a case, the syndicate that sent the watchdog at fault would also be held responsible and could be sued by the damaged firm.

I now come to another key behavioural difference between the firms under the control of the FS and the capitalist firms, and explain why the firms of the FS may reasonably be described as public-democratic firms. The FS instructs its firms to maximize their profits, the same instruction that capitalists give to their firms. However, the behaviour of the public firms would differ by the extent to which they empower their employees in the governance of the firm. The staff of the FS in the supervisory boards would namely seek to revive the role of worker participation and at the same time foster a sense of identification of the employees with their firm and the FS - the public institution embodying the endeavour of the polity to get rid of capitalist dominance. Thus, the participation of workers in the management of public firms, through works councils and other agencies of co-determination, would be a major difference between public and private firms.

Capitalist firms often try to promote employees' identification with the firm. But, as a rule, they cannot make appeal to the common good and a project of society. I surmise that for that reason the employees of the firms in public ownership will exhibit more altruism towards their employer than the employees of private firms. ${ }^{21}$ That is, the employees of the firms of the FS will be especially willing to exert extra efforts that help their firm to thrive. This form of identification with the firm can in turn mitigate the hold-up problem associated with the establishment of voice mechanisms that activate the workforce within the firm. Because of that problem, capitalists give worker institutions within the firm less power than is socially optimal. At the margin, granting more co-determination to workers in a capitalist firm is likely to increase labor productivity by improving communication flows inside the firm. But co-determination also improves the ability of workers to self-organize for bargaining purposes and ex-post it allows them to reap a larger share of the surplus generated by the firm. Therefore, capitalists fail to set up institutions of worker participation that maximize production efficiency, so that even in this narrow sense they empower workers too little (Freeman and Lazear, 1995). ${ }^{22}$

The enhanced altruism toward the employer in the case of the firms of the FS works as a commitment device that lessens the hold-up problem by reducing the share of the cake demanded ex-post by the workers. Since the extent of worker participation in capitalist firms is inefficiently low, once one of them is acquired by the FS productivity can be increased by setting up institutions that generate greater worker involvement. At the same time, public ownership makes employees identify more closely with the company they work for. Since this

\footnotetext{
${ }^{21}$ This may occur because altruists self-select in the public firms and/or because altruism is increased by the sense of mission attached to the FS.

${ }^{22}$ Mandatory co-determination in Germany is an example of far-reaching worker empowerment that has been forced upon companies having more than 500 employees. The empirical literature suggests that it has small but positive effects on productivity and innovation - as measured by patents - and no negative effects on profitability (Addison and Schnabel, 2011).
} 
reduces the share of the surplus that is demanded by the employees in wage negotiations, establishing more co-determination ultimately pushes up also firm's profits. Therefore, the requirement that the FS put special emphasis in promoting worker participation is not an additional goal of that institution but the distinctive channel through which it attains the goal of profit maximization. One by which the public-democratic firms of the FS may be able to outperform the capitalist firms. ${ }^{23}$

The capitalists thus deprived of corporate control would no longer be in a position to exert a major influence on political decision-making. This would help to break the vicious circle of increasing wealth concentration and political capture. However, the economic power formerly enjoyed by capitalists and their managers does not dissolve by transferring control to the FS. It takes a new form: private controlling shareholders are replaced by the representatives of the FS, the firms' managers now cooperate with works councils, while trade unions, consumer protection agencies and environmental associations have supplementary information rights. Despite these changes, one might be concerned that the firms of the FS are large organizations instructed to maximize profits and that such organizations may be tempted to use their economic power to distort the political process in much the same way capitalist firms do.

Large firms under the control of the FS would indeed be likely to exert some special influence on the political process, but that influence would markedly differ from the one exerted by today’s corporations. Capitalist firms, coordinated by their associations and lobbies, devote a considerable amount of resources to foster the interests of the capitalist class in the political arena. An example is the generous contributions they make to politicians and think-tanks that actively promote the repeal of the estate tax. The staff of the FS that replaces the capitalists in firm supervision would hardly expend any effort at all on such a matter. Because of their different social background and personal economic conditions, the representatives of the FS would not disproportionately gain from a repeal of the estate tax. More generally, capitalist firms have not only owners who stem from the wealthiest fractiles of the population, but also the CEOs that they recruit tend to be similar to them, i.e. come from the upper class. In public firms and public institutions the social background of the members of the boards of directors tends to be much more diverse. ${ }^{24}$ This means that the endorsed values and political ideals of those in charge of controlling the public-democratic firms will be more progressive than those of capitalists and their managers. Hence, also their impact on the political process will be a more progressive one.

Nowadays, corporations often buy political influence in order to obtain policy measures that increase their profits. Examples include polluting industries demanding to be exempted from ecological taxes, banks demanding light capital regulations, agricultural conglomerates demanding protection through tariffs, oil companies demanding military interventions in oil-

\footnotetext{
${ }^{23}$ Since the optimal extent of worker participation is likely to be firm specific, the firms of the FS should be free to choose the institutions through which they want to implement more worker participation. For instance, the FS could offer a menu of co-determination charters from which each firm may select the one that is expected to generate the highest profit over the long run.

${ }^{24}$ See e.g. Hartmann (2007) on Germany and Italy.
} 
rich countries, and car producers demanding high speed limits on highways. The increase in profits comes with an increased amount of some public bad. The lobbying firms get the profits and society at large carries the costs associated with the public bad. Would the firms under the control of the FS reduce the amount of lobbying effort that aims at increasing their own profit through more public bad? I think so. The FS is a public institution with a raison d'être that transcends profit maximization, namely to help creating a society where equal democratic participation is not thwarted by the overwhelming economic power of the wealthy. Thus, one may expect the staff of the FS in the boards of the firms to have internalized the value of democracy and therefore to experience feelings of guilt whenever trying to subvert democracy in order to increase firm profits. By the same token, they would condemn such behaviour in others, e.g. in their colleagues. This implies that the firms of the FS will be less prone than their capitalist counterparts to buy political favours at the expense of the majority of the population.

One might argue that the reduced propensity to lobby by the public-democratic firms will backfire by negatively affecting their competitive edge relative to the capitalist firms. This need not be the case for two reasons. First, socially responsible consumers are likely to recognize that lobbying is socially harmful and therefore decide to vote with their wallet in favour of public-democratic firms - as those firms are unlikely to lobby for a public bad. Those individuals may similarly discriminate in favour of stocks of the public-democratic firms when making their portfolio decisions. By the same token, voting with the wallet may more than compensate the costs to the public-democratic firms of providing extra-information to trade unions, consumer protection organizations, and environmental groups. Second, lobbying typically triggers an increase of profits at the level of an entire industry rather than for a single firm, and firms cannot be excluded from industry profits on the basis of their lobbying efforts. For instance, the rule of no general speed limit in Germany's highways benefits all producers of relatively fast cars, independently of their connections to the German government. This means that the firms of the FS that refrain from lobbying would free-ride on the lobbying efforts of their capitalist competitors.

A priori it is unclear how well the public-democratic firms would perform in comparison with capitalistic corporations. The establishment of the FS should therefore be viewed as an openended challenge about the ability of the polity to replace capitalist control of large firms by public-democratic control. Conventional wisdom takes for granted the superiority of private control of firms, but this view is often grounded on the crucial role played by ownerentrepreneurs in small and medium-sized businesses. As far as large firms are concerned, claims of such a superiority are far-fetched. ${ }^{25}$ Capitalistic corporations are often plagued by governance problems: they are sometimes run by incompetent heirs who love to exert power on other people, occasionally they are preyed upon by their own managers, and in general they fail to empower their employees so as to reap in full the efficiency gains from voice mechanisms. Hence, it is by no means evident that having active public ownership of large

\footnotetext{
${ }^{25}$ Acknowledging this, the OECD (2015) has recently released guidelines on the governance of public firms.
} 
firms governed by a well-designed incentive structure cannot beat capitalists on their own ground, i.e. in terms of rates of return.

The final partition of the corporate sector between private-capitalist and public-democratic control should not be set in advance. Rather, it should be the outcome of a collective learning process. Once the FS has been established and the first few corporations placed under its control, a market-driven selection process will follow that will lead in time to an optimized partition. Given a level playing field where both forms of governance can compete fairly on even terms, and externalities are internalized, their relative profitability will mirror their relative efficiency. The more profitable governance form will expand and the other will shrink, until the efficient partition is arrived at. In the course of this process the more efficient companies will be more profitable, and the higher returns they offer will mean that their shares are more in demand; consequently more capital will flow into the more efficient companies, and their market share will grow. If these are the public-democratic firms, this will contribute to prevent democracy from turning into plutocracy and to promote worker participation in the management of firms.

Should the FS eventually turn out to be too successful - i.e. a large fraction of the corporate sector become public-democratic - the polity may want to reform the institutional framework of public ownership so as to dilute the economic power embodied in the FS and foster pluralism in corporate control. At that stage, various routes could be envisaged. One possibility is to distribute the stocks of the FS to a myriad of municipally owned investment funds, as proposed by Stauber (1987). Those locally owned funds would then act independently in a competitive market for corporate control. Another possibility is to distribute the stocks of the FS directly to the individual citizens in a way that prevents the resurgence of capitalistic dominance. Roemer (1994) shows how to accomplish this by redenominating the stocks in a special currency only used in the stock market, distributing that currency equally among the individuals when they enter adulthood, and socializing their stock portfolios when the individuals pass away. ${ }^{26}$

\section{Building a stock of public capital}

Readers who think that the evolutionary approach sketched above could contribute to solve problems (1)-(3) may want to step back and consider the problem of putting in place the initial level of public capital. The novel SWF has to be endowed with a stocks portfolio amounting to some thirty to fifty points of GDP. How may the government finance the corresponding public expenditures? Barring windfalls from natural resources, I propose that the government utilize three main sources of financing: privatizations, government bonds, and capital taxes. As argued below, in this way a relatively large public capital can be gradually built at small social costs.

\footnotetext{
${ }^{26}$ Corneo (2014b) discusses the pros and cons of both arrangements as well as the relationship between publicdemocratic firms and private entrepreneurship.
} 
The first source of financing to be used is proceeds from privatizations - which might include sales of emission rights, licences for the use of airwaves, and gold reserves. Its relevance is highly country-specific and depends on circumstances. In some countries, some assets are in public ownership because of historical reasons that are no longer compelling. By way of an example, in the wake of urbanization several countries built a large public capital stock in form of flats to be rented at special conditions to the needy. Today, that kind of public ownership may be no longer warranted to the same extent and its size may be considerably reduced. Other countries still have significant public ownership in manufacturing and infrastructure industries. To the extent the strategic reasons that motivated it are no longer valid, some of that property may be used to endow the SWF.

As a second source of financing, the government should consider issuing new debt. Globally, the real interest rate has declined over the last three decades and in triple-A countries the long-run real interest rate on government bonds is now close to zero (King and Low, 2014). This makes government debt a valuable option to finance the SWF. As long as the interest rate paid by the government is lower than the growth rate of GDP, the debt incurred to endow the SWF would keep decreasing relative to GDP and it would eventually vanish in relative terms if that situation persists indefinitely. In this case, the issuing of new public debt would raise no concerns of debt sustainability.

If the current low level of interest rates is temporary, the interest rate on government bonds will likely be higher than the growth rate in the future. But even in that case, countries with a high financial standing may increase their gross public debt in order to endow the SWF without affecting debt sustainability. The reason is that the interest rate on government debt can be expected to be considerably lower than the rate of return that the SWF earns on its stocks. Then, the government can announce that the income of the SWF will be prioritized to cover its interest payments. If, for example, the stocks in public ownership yield over the long term a rate of return of $8 \%$ and the interest paid on government bonds is $2 \%$, one-fourth of that rate of return suffices to cover the government's refinancing costs. With some GDP growth, this implies again that the incurred debt would asymptotically vanish in relation to GDP. Since the difference between the rate of return on the stocks and the interest rate on government debt would be used for the social dividend, this strategy is tantamount to socializing the equity risk premium. According to Mehra (2008), the equity risk premium in the past century used to be in the range $7 \%-9 \%{ }^{27}$

If this is not enough to maintain a country's financial reputation, the government could announce that the obtained net financial return will be prioritized for paying down the debt

\footnotetext{
${ }^{27}$ Retrospectively, stocks have very rarely underperformed bonds over periods of time of two or three decades. Of course, the time at which the SWF purchases its stocks should be a matter of concern. The power to tax allows the government to credibly promise to repay the incurred debt even in case of low stock returns, which explains why the same financial strategy cannot be adopted by individuals. As pointed out by Varian (1980), income-related taxes work as an insurance device, spreading risks in a way that can be superior to incomplete financial markets. Capital-market imperfections - including the factors that explain the "stock market participation puzzle" mentioned in fn. 8 - imply that the bond-financed equity investment performed by the SWF can be welfare-increasing; see the general-equilibrium analyses by Grant and Quiggins (2002) and Diamond and Geanakoplos (2003).
} 
incurred to set up the SWF. After a period of fifteen to twenty years, the new borrowing to purchase the stocks would almost certainly have been repaid and the gross public debt of the country would then have returned to its initial level. Only then, would citizens begin receiving the social dividend.

The three scenarios depicted above entail a temporary increase of gross public debt and no appreciable effect on the debt to GDP ratio in the long run. Alternatively, the formation of public capital could come along with a permanent increase of that ratio. In several countries, demographic change brings about a long-lasting increase in private households' demand for safe assets to finance consumption during retirement. According to von Weizsäcker (2014), this rise of savings cannot be matched by an increase of real investment and should be accommodated by means of a higher public debt. Liquid, inflation-indexed long-term government bonds would offer households a reliable instrument to smooth their consumption over time, while being a cheap form of debt financing for the government (Campbell et al., 2009).

In the case of a large country, such an emission of new public debt could have a first-order effect on the worldwide supply of fixed-income securities, causing the equilibrium level of the risk-free interest rate to increase. Under present conditions, this effect is likely to be moderate. The risk-free interest rate is close to zero and at that level the demand for risk-free assets is almost flat. By continuity, this suggests that a first-order addition to the offer of riskfree financial assets is likely to produce a small effect on the interest rate. ${ }^{28}$ In turn, a moderate increase of interest rates is likely to generate positive macroeconomic effects by reducing the risk that monetary policymakers are constrained by the zero lower bound on the nominal interest rate and by decreasing the risk of financial instability (Kocherlakota, 2015).

Arguably, matters are rather different once we turn to the impact of the SWF's purchase of stocks on their price. ${ }^{29}$ Purchases of the order of some GDP-points of a large country would have a first-order impact on stock prices and possibly generate a stock-market bubble. Moreover, by reducing the returns on the purchased stock, the government's net financial gain from emitting debt to acquire stocks would be reduced. While stretching the stock purchases over a longer period of time would make sense, in the case of a large country it may not suffice. The stock purchases by the SWF should therefore be accompanied by policies that increase the net supply of stocks by the private sector. Here is where the third source of financing I propose - capital taxes - comes in.

\footnotetext{
${ }^{28}$ By way of an example, between 2008 and 2010 the level of the gross public debt of Germany increased by almost one fourth or some fifteen GDP-percentage points. During the same period of time, the financial costs of the German government did not increase, they decreased.

${ }^{29}$ Under conditions of Ricardian equivalence there would be no effects as long as private investors have stocks in their portfolios that can be sold to buy the additional public debt. But in reality, various kinds of transaction costs severely constrain the financial investment of small savers and their ability to take risks. Caballero and Farhi (2015) formalize the idea of a deflationary safety trap and show that swapping private risky assets for public debt can stimulate the economy. Admati and Hellwig (2013) recommend forestalling various instances of moral hazard that characterize the behavior of financial intermediaries by requiring high levels of equity funding. The creation of a SWF that is financed by public debt and invests in stocks would promote such a change in the capital structure of financial intermediaries and thus contribute to making them more resilient.
} 
Capital taxation can namely fulfil a double function: it can avert a stock-market bubble and contribute to finance the SWF. This can be achieved by introducing or increasing a

- tax on stock market transactions,

- tax on capital gains,

- inheritance tax.

The SWF would be exempted from those taxes. Their revenue would be earmarked to endow the SWF, until it has reached the desired size. Over time, even moderate tax rates would allow the polity to build a relatively large SWF.

The transaction tax and the tax on capital gains should include equity derivatives, and the one on capital gains should be progressive. They will reduce the net demand for stocks by private investors and hence the probability of creating a stock market bubble. A highly progressive inheritance tax with a generous exemption threshold may usefully complement them. Stock ownership at death is highly concentrated in the largest estates. Hitting them with a high tax rate would prompt inheritors to sell a part of the inherited stock, which would negatively affect the price of stocks.

Summing up, putting in place a SWF does not need to strain public finances. A mix of privatizations, new government debt and somewhat higher capital taxes can be used in order to gradually build a substantial public capital at negligible social costs. Needless to say, different countries may want to choose different combinations of those financing sources depending on country-specific circumstances.

\section{Conclusion}

A high level of wealth inequality is a threat to both shared prosperity and democracy. Public capital can play an important role in counteracting that threat. It can generate a social dividend that is received by every citizen and it can spur individuals' participation in their workplaces and the political arena. In this way, public capital can break the vicious circle of increasing wealth concentration and political capture, contribute to more equality of opportunity, and reduce the transaction costs of financial investment. The role of public capital should be enhanced through a carefully designed evolutionary process of institution building. That process should start by creating a socially responsible SWF that acts as a collective rentier, investing worldwide in stocks so that every citizen shares in the high returns generated by the stock market. If this institution proves to be successful, a second one should be introduced that activates public ownership by contesting capitalists' control over some large firms. I have called that institution Federal Shareholder. It would empower the employees of the firms it controls, enhance their transparency, and inject a more progressive mood in the political discourse. Together, the socially responsible SWF and the Federal Shareholder would considerably rebalance people's access to material goods, social 
recognition and autonomy and lead to a more pluralistic market economy - one more attuned to the democratic values of a truly open society. 


\section{REFERENCES}

Addison, John T. and Claus Schnabel. 2011. "Worker Directors: A German Product that Did Not Export?” Industrial Relations 50, 354-374.

Admati, Anat and Martin Hellwig. 2013. “The Bankers’ New Clothes.” Princeton: Princeton University Press.

Al-Hassan, Abdullah, Papaioannou, Michael, Skancke, Martin and Cheng Chih Sung. 2013. "Sovereign Wealth Funds: Aspects of Governance Structures and Investment Management." IMF Working Paper 13/231.

Atkinson, Anthony B. 2015. “Inequality.” Cambridge: Harvard University Press.

Barberis, Nicholas and Ming Huang. 2008. "The Loss Aversion/Narrow Framing Approach to the Equity Premium Puzzle.” In: Mehra, Rajnish (Ed.), "Handbook of the Equity Premium.” Amsterdam: Elsevier.

Becchetti, Leonardo, Ciciretti, Rocco, Dalo, Ambrogio and Stefano Herzel. 2014. "Socially Responsible and Conventional Investment Funds: Performance Comparison and the Global Financial Crisis.”, RCEA Working Paper 04_14.

Bernstein, Shai, Lerner, Josh and Antoinette Shoar. 2013. „The Investment Strategies of Sovereign Wealth Funds.“ Journal of Economic Perspectives 27, 219-238.

Bönke, Timm, Corneo, Giacomo and Holger Lüthen. 2015. "Lifetime Earnings Inequality in Germany.” Journal of Labor Economics 33, 171-208.

Bruni, Luigino and Stefano Zamagni. 2007. "Civil Economy: Efficiency, Equity, Public Happiness.” Oxford: Peter Lang.

Caballero, Ricardo J. and Emmanuel Farhi. 2015. “The Safety Trap.” Mimeo MIT and Harvard.

Campbell, John Y., Shiller, Robert J. and Luis M. Viceira. 2009. "Understanding InflationIndexed Bond Markets.” NBER Working Paper 15014.

Corneo, Giacomo. 2014a. "Public Capital in the 21 ${ }^{\text {st }}$ Century." Social Europe Journal, Research Essay 2.

Corneo, Giacomo. 2014b. „Bessere Welt.” Vienna: Goldegg. English translation: Cambridge: Harvard University Press, forthcoming.

Dagger, Richard. 2006. “Neo-Republicanism and the Civic Economy.” Politics, Philosophy \& Economics 5, 151-173.

Diamond, Peter and John Geanakoplos. 2003. "Social Security Investment in Equities." American Economic Review 93, 1047-1074.

Dietzenbacher, Erik and Umed Temurshoev. 2008. „Ownership Relations in the Presence of Cross-Shareholding.“ Journal of Economics 95, 189-212. 
Dorofeenko, Victor, Lang, Larry, Ritzberger, Klaus and Jamsheed Shorish. 2008. "Who controls Allianz?” Annals of Finance 4, 75-103.

Freeman, Richard and Edward Lazear. 1995. “An Economic Analysis of Works Councils.” In Rogers, J. and W. Streeck (eds.), "Work Councils”, Chicago: University of Chicago Press.

Goldsmith, Scott. 2012. "The Economic and Social Impacts of the Permanent Fund Dividend on Alaska.” In Widerquist, K. and M. W. Howard (eds.), “Alaska's Permanent Fund Dividend”, New York: Palgrave Macmillan.

Grant, Simon and John Quiggin. 2002. "The Risk Premium for Equity: Implications for the Proposed Diversification of the Social Security Fund.” American Economic Review 92, 11041115.

Grinblatt, Mark, Keloharju, Matti and Juhani Linnainmaa. 2011. „IQ and Stock Market Participation.“ Journal of Finance 66, 2121-2164.

Guiso, Luigi, Sapienza, Paola and Luigi Zingales. 2008. “Trusting the Stock Market.” Journal of Finance 63, 2557-2600.

Hartmann, Michael. 2007. “Eliten und Macht in Europa.” Frankfurt: Campus.

King, Mervyin and David Low. 2014. “Measuring the "World” Real Interest Rate.” NBER Working Paper 19887.

Kocherlakota, Narayana. 2015. "Public Debt and the Long-Run Neutral Real Interest Rate.” Bank of Korea Conference.

Kopczuk, Wojciech, Saez, Emmanuel and Jae Song. 2010. “Earnings Inequality and Mobility in the United States: Evidence From Social Security Data Since 1937. Quarterly Journal of Economics 125, 91-128.

Lessig, Lawrence. 2011. “Republic, Lost.” New York: Twelve.

Meade, James. 1965. “Efficiency, Equality, and the Ownership of Property.” Cambridge: Harvard University Press.

Mehra, Rajnish. 2008. “Handbook of the Equity Premium.” Amsterdam: Elsevier.

Morck, Randall, Wolfenzon, Daniel and Bernard Yeung. 2005. "Corporate Governance, Economic Entrenchment, and Growth.” Journal of Economic Literature XLIII, 655-720.

Nichols, John and Robert W. McChesney. 2014. “Dollarocracy.” New York: Nation Books.

Nofsinger, John and Abhishek Varma. 2012. "Socially Responsible Funds and Market Crises.” Mimeo. Washington State University.

OECD. 2015. “OECD Guidelines on Corporate Governance of State-Owned Enterprises.” Paris: OECD Publishing.

Piketty, Thomas. 2014. "Capital in the Twenty-First Century." Cambridge: Harvard University Press. 
Piketty, Thomas and Gabriel Zucman. 2015. "Wealth and Inheritance in the Long Run.” In Handbook of Income Distribution, Vol. 2B. Amsterdam: Elsevier.

Quadrio Curzio, Alberto and Valeria Miceli. 2010. "Sovereign Wealth Funds: A Complete Guide to State-Owned Investment Funds.” Petersfield: Harriman House.

Roemer, John E. 1994. “A Future for Socialism.” Cambridge: Harvard University Press.

Saez, Emmanuel and Gabriel Zucman. 2016. "Wealth Inequality in the United States Since 1913: Evidence From Capitalized Income Tax Data.” Quarterly Journal of Economics 131, 519-578.

Standing, Guy. 2014. “A Precariat Charter.” London: Bloomsbury Academic.

Stauber, Leland. 1987. “A New Program for Democratic Socialism.” Carbondale: Four Willows Press.

Stiglitz, Joseph E. 2012. “The Price of Inequality.” New York: Norton.

Stiglitz, Joseph E. 2015. „New Theoretical Perspectives on the Distribution of Income and Wealth Among Individuals: Part II: Equilibrium Wealth Distributions.“ NBER Working Paper 21190.

Trabandt, Mathias and Harald Uhlig. 2011. “The Laffer Curve Revisited.” Journal of Monetary Economics 58, 305-327.

Varian, Hal. 1980. "Redistributive Taxation as Social Insurance.” Journal of Public Economics 14, 49-68.

Von Weizsäcker, Carl Christian. 2014. "Public Debt and Price Stability.” German Economic Review 15, 42-61. 